\title{
Addressing English Writing Problems for College Students through Integrated Approaches
}

\author{
Xiu Zeng \\ Foreign Lauguage School, Nanchang Normal University, Nanchang, Jiangxi, 330032 \\ 2267395464@qq.com
}

Keywords: Approaches; College students; English writing problems; Integration

\begin{abstract}
Writing is an extremely important means of communication in the modern world, either in the traditional form or through e-mail. However, English writing has long been viewed as a challenge to most Chinese college students because of their weak language foundation, limited expanse of ideas and less targeted practice for the production of satisfactory written work. Attention has long been directed to the low efficiency in the writing teaching. By adopting an integrated approach of product writing and process writing, this paper tries to explore a way to employ the two approaches in the solution of problems in the teaching of English writing. The focus of this paper is put on the suggested solutions and the improvement in the efficiency of English writing teaching.
\end{abstract}

\section{Introduction}

Writing is not only one of the four basic language skills in English learning, it is also an important means of exchange of ideas in social life. It is usually considered to be a sign of one's language competence and comprehensive quality. But for most Chinese learners, English writing is still a big problem. Students at university level suffer from a limited lexicon and weak language foundation though they work hard and do well in reading exam. Further, they often have difficulty organizing their ideas in proper ways, or even they are usually short of ideas for a given topic. As far as some students are concerned, 'producing a piece of writing has always come after a period of suffering' and they are 'experiencing complete and total anxiety over writing' (Winer1992)[1]. To get students out of the plight, to improve their writing power and efficiency of writing teaching, here in this paper it is suggested that both product writing and process writing be introduced to play different roles to produce combined effect.

\section{A Research into the Causes of Students' Weak Performance in Writing}

For majority of Chinese students, English is a second language that is taken as a compulsory course in both high school and university. In spite of the fact that much time and efforts have been devoted to the learning in their secondary school, they still cannot make proper use of English to express themselves in college. Possibly I suppose the following may be the causes:

First, many college students come from the provinces relatively backward in the development of economics and education, especially from the isolated areas in the countryside, where there is always an urgent need for the qualified teachers of English, which greatly affects the English level of new students in colleges.

Second, students have seldom been required to do real writing before getting higher education though they have studied English for six years. Neither have they been trained with specific skills. Their writing task then was only the translation of sentences or paragraphs as required. As a result, they are generally considered to be unskilled writers.

Third, students are often asked to write about what they are not familiar with or what they are not interested in. They have not gone through many different lives and developed much their own views, what they have acquired from text learning does not meet the requirements of writing tasks. Therefore, they are not well prepared for different types of writings. 
For the above-mentioned causes, students often run into difficulty in writing and such unsuccessful experience discourages them from writing competently with confidence. It is quite easy for students to give English writing up or put it to a position secondary to the other language skills. This is what this paper mainly intends to address.

\section{Literature Review on Process and Product Writing}

Process Writing. In 1972, Donald M. Murray published a brief manifesto titled "Teach Writing as a Process Not Product" [2], a phrase which became a rallying cry for many writing teachers. Ten years later, in 1982, Maxine Hairston argued that the teaching of writing had undergone a "paradigm shift" in moving from a focus on written products to writing processes[3].

The process writing approach involves teaching pupils strategies to help them express themselves in writing through the act of writing (Mahon, 1992) [4]. Students experience five interrelated phases before the final products come out. The five important steps in process writing include pre-writing phase, brainstorming, drafting, revising and editing, finished product.

Process writing breaks the writing acts into manageable parts and it integrates oral language, reading and writing in meaningful writing task. It allows students to concentrate on one task at a time and to experience the value of peer feedback in developing their ideas for effective written expressions.

Product Writing. This is a traditional approach, in which students are encouraged to mimic a model text, which is usually presented and analyzed at an early stage. In model texts study, students' attention may be drawn to the importance of paragraphing and the language, the focus may be put on the techniques used in organizing sentences and paragraphs. Organization of ideas is believed to be more important than the ideas themselves and as important as the control of language.

Further, students choose from a choice of comparable writing tasks. Individually, they use the skills, structures and vocabulary they have been taught to produce the product to show what they can do as fluent and competent users of the language. In product writing, more emphasis is put on the end result of the required composition.

\section{Addressing the Common Writing Problems}

Building Language Foundation through Reading. Reading, as one of the essential skills of communication, has long been recognized to play a significant role in the overall acquisition of any language, the same is true of its role in the development of students' writing ability. As Gebhard (1996) pointed out that the useful things in writing are word choice, use of appropriate grammar, syntax, mechanics and organization of ideas into a coherent and cohesive form [5]. "In both in-school and out of school context, reading and writing serve as integral processes in learning new information, in translating information, for making sense of new ideas and for communicating those new ideas with others"'[6]. It is chiefly through reading process that students can accumulate vocabulary, build solid language foundation and grow familiar with the organization of an essay, all of which makes the completion of a piece of good writing possible.

In terms of linguistic competence, poor command of vocabulary and inability to use it properly may be one of the major obstacles in the preparation for written work for Chinese college students. Vocabulary is often more important and challenging than grammar in that vocabulary is very infinite and words are often more complex than they appear to be, for words are not isolated from but associated with a certain type of context or situation [7]. thus they behave differently in different context. Therefore, special attention has to be directed to the meaning and usage of words and expressions in text reading.

Further, it is important to recognize that students do not learn from the first presentation of the new language items alone. They need to be introduced or even reintroduced to the new items until they can have a full command of what they have learnt and produce them automatically when required. To reach this goal, students are often asked to practice a certain number of language 
models, such as word substitution, sentence patterns, structure of paragraphs, etc. In many English textbooks, there are always such items of exercise " replace A with B", "reorganize the following sentences after the models" or "compose a paragraph on the provided structure", etc. The repeated phrases and structures are usually the most often used ones. To be familiar with them is really a great advantage for students to be fluent users of English in writing.

It has been acknowledge that various forms of input such as vocabulary, language patterns, model writing and reading are prerequisite to students' development in the aspects of ideas generation and writing skills. Structured and semi-structured practices are essential to building up students' capacity in using the language forms functionally. Yet, a careful balance must be kept between substantive language input and room for the cultivation of creativity intended for the writing process.

Exploring Knowledge and Cultivating Creativity. In the reading of my students' papers, I always find students are rather weak in expanding paragraphs with different ideas or from different perspectives. It seems that they cannot venture beyond the instruction of teachers and textbooks for the cause of their limited absorption of knowledge and fixed ways of thinking, thus their writing can be very dull and dry, let alone free creation. To solve the problem, I think exploring reading and cultivation of creativity are much valuable.

Generally, the value of an excellent piece of writing does not only fully lie in its correct use of words, grammar and coherent organization, but equally lie in the ideas it produces and feelings it conveys. Those masterpieces that have inspired or shaped generations of readers are mostly originated from the minds that do so much reading, thinking and exploring that they gain the unique perception of the world inaccessible to ordinary people. Then it follows that value of a writing also depends on what a writer can communicate or share with a reader.

In the course of text reading, teachers cannot be much satisfied that students have understood what words seeming convey to them. We should go further to ask students to explore what is hidden under the lines, what is most instructive and enlightening to them. After class, mind-improving books will be introduced as a supplementary reading task to push back their horizon and enrich their inner world, for these readings are treasure of learning and a rich source of human civilization. from which young students can constantly learn the meaning of beauty, wisdom and life and will then cherish it all their lives. A student writer nurtured with such education is expected to create a piece of compelling work.

To nurture in learners creative spirit is one of the fundamental goals of quality-oriented education and also the contributing factor for attainment of originality in writing (Chen Qingsong, 2005)[8] .Writing, like the art of painting, is a type of creative mental activity. Originality is highly valued in the process of creation of written work. A writer is usually as much appreciated for his creativity in his work as a painter is in his art work. Because of the important role that creativity plays in the production of written work, teachers should include fostering of creative power in the whole process of writing teaching, in students' life experience, even in every aspect of their life.

Just as Anatole France says "the whole art of teaching is only the art of awakening the natural curiosity of young mind for the purpose of satisfying it afterwards". To have curiosity about an unknown world, to have dream about future and to have imagination over what they long for are the common traits among young people. It lies heavily on teachers' shoulders to awaken, activate and satisfy all these to promote life-long creative spirit in them. It is also a teacher's duty to encourage students to try out new approaches to familiar topics or to view them from different perspectives, or even to question what has been long established. Being constantly guided to this direction, students will gradually learn to think for themselves and develop new, free ways of thinking. Then he will no longer find the completion of a piece of creative work threatening or forbidding.

Providing Supportive Environment. Ann Ramie's (1983) [9] says "For second language learners, who need more time and opportunity to practice using the language with others, group work is especially beneficial. For teachers, collaboration is an effective way of teaching and it is very important in our professional development". Likewise, for students, the co-learning practice 
enables peer learning and experience sharing. It makes learning more effective and fruitful. For example, in the five important steps in process writing such as pre-writing phase, brainstorming, drafting, revising and editing, finished product, group work plays an important role. In brainstorming stage, students can freely associate and exchange ideas with their peers in groups, they can make up for each other's deficiencies, learn from each other and meet each other's needs. Their imagination can be inspired by so many different ideas from peers that they no longer worry about inadequacy of ideas. As a result of sharing ideas, students do not fear their ideas will be rejected by teachers, for they would have the whole group to back themselves up, which promotes confidence and interest to write and also improves quality in writing.

In revising and editing stages, students are often asked to read each others' work, either in pairs or in groups, and give comments to each other for revision before the final draft is handed in and assessed by the teacher. Students like to incorporate the exchanging of drafts to become the readers of each others' work. This is an important part of the writing experience as it is by responding as readers that students develop an awareness of the fact that they are producing something to be read by someone else. A great deal of excitement is generated when they know that they will share their final product with others. "As the students see their writings read by others, the sense of achievement is great and this will encourage them to write more. Displays and sharing their works make their writing authentic and it is a good way to promote writing. (Peregoy and Boyle, 1993) [10].

Integrating Product Writing and Process Writing. Both product writing and process writing are equally important, the two approaches are not necessarily incompatible, they have respective strength and weakness, the best practice in any situation will depend on the type of student, the text type being studied and many other factors.

Generally, for Chinese college students, English is a second language, in which they receive insufficient specialized training and little regular practice in language production. According to Carroll (1984) [11], the process approach is believed by many teachers to be inappropriate for students whose English is limited. It is essential that teachers be strict with students in" word choice, use of appropriate grammar, syntax, mechanics and organization of ideas into a coherent and cohesive form' Gebhard (1996). Teachers have to emphasize the production of neat and grammatically correct pieces of compositions by using structured sentence patterns and controlled vocabulary so that later students can go on writing smoothly. Such a product-orientated approach prepare students technically for the start and completion of composition and then for error correction in a final revised form of writing.

But on the other hand, process approach to writing tend to focus more on the varied classroom activities which promote the development of language use: brainstorming, group discussion, editing and re-writing. In the whole course of process writing, the most important thing is the flow of ideas, the teacher needs to stimulate students' creativity, to get them thinking how to approach a writing topic: how to generate ideas by brainstorming and discussion; how to extend ideas, and judge quality and usefulness of ideas; how to organize ideas into drafts: how to revise drafts based on peer feedback. It is a complex mental activity and collaborative work, which contributes much to the improvement of writing quality.

Both product and process approach play a shared role in the promotion of progress in the writing power of college students. As Raimes (1985) [12] points out, writing teachers should "consider the need to attend to product as well as process. Our students should be taught not only heuristic devices to focus on meaning, but also heuristic devices to focus on rhetorical and linguistic features after the ideas have found some form". In other words, it is not a matter of adopting one approach for certain students, but rather a matter of marrying the two (Conner1987) [13].

\section{Conclusion}

To sum up, learning to write is a long, complex and creative process in which a series of language practice and the related activities are involved and interrelated [14]. On the one hand, well-targeted 
and extended reading helps to bring about proper, fluent and well-organized creation of writing. On the other hand, constant exposure to different sources of thought through different designs works to improve the mind of students. Therefore, writing practice, like the practice of the other language skills, is a part of language learning and a part of quality-oriented education. If English teachers have a deep understanding of the interrelation between writing and the contributing factors, place equal stress on language form and content, integrates writing into the whole process of teaching, then all the efforts made by teachers and students will be much rewarded.

\section{References}

[1] Winer, L. (1992)'Spinach to chocolate': Changing awareness and attitudes in ESL writing teachers. TESOL Quarterly26 (1):57-59. http://dx.doi.org/10.2037/3587369.

[2] Donald M. Murray, (1972). "Teach Writing as a Process Not Product" The Leaflet (November, rpt. in Cross-Talk in Comp Theory, 2nd ed., ed. Victor Villanueva, Urbana: NCTE, 2003.

[3] Maxine Hairston, (1982). "The Winds of Change: Thomas Kuhn and the Revolution in the Teaching of Writing" CCC 33 (1982), pp. 76-88, rpt. in the Norton Book of Composition Studies, ed. Susan Miller, New York: Norton. http://dx.doi.org/10.2307/357846.

[4] Mahon, T. (1992). From sentence to story: A process approach to the development of composition skills in the primary school. In Lau, M. \& Murphy, M. (Eds.) Developing writing: purposes and practices. Hong Kong: Institute of Language in Education, Education Department.

[5] Gebhard, J.G. (1996). Teaching English as a Foreign or Second Language [M]. The University of Michigan Press.

[6] Mulcainy-ernt.P and Stewavt.J. (1994).Writing and Reading in integrated language Arts: Ibid.

[7] Laflamme and John G. s (1997). The effect of multiple exposure vocabulary method and the target reading /writing strategy on test scores [J]. Journal of Adolescent \& Adult Literacy, 40(5): 372-384.

[8] Chen Qingsong. S (2005). On constructing new concept of English writing instruction [J].Teaching English in China. 4:107-110.

[9] Ann Raimes, (1983). Techniques in Teaching Writing [M]. Oxford University Press.

[10]Peregoy, S and Boyle, O. (1993). Reading, writing and learning in ESL. A resource book for K-8 teachers. New York: Longman

[11]Carrol, J.A. (1984). Process into product: Graduate school and beyond. New York: Guildford, pp. 315-333.

[12]Raimes, A. (1985). What unskilled ESL students do as they write: A classroom study of composing. TESOL Quarterly 19(2):229-358. http://dx.doi.org/10.2307/3586828.

[13]Connor, U. (1987). Research frontiers in writing analysis. TESOL Quarterly 21(4): 677-696. http://dx.doi.o rg/10.2307/3586989.

[14]L.M. Yang. (2002).New College English, Shanghai Foreign Language Education Press. 